\title{
Effect of Social Skills Training: Social Interaction Capabilities towards Social Isolation Clients
}

\author{
Hanik Endang Nihayati \\ Faculty of Nursing Universitas Airlangga \\ Surabaya, Indonesia \\ hanik-e-n@fkp.unair.ac.id \\ Andri Septyas Pranu Junata \\ Faculty of Nursing Universitas Airlangga \\ Surabaya, Indonesia
}

\author{
Rr Dian Tristiana \\ Faculty of Nursing Universitas Airlangga \\ Surabaya, Indonesia
}

\author{
Ah. Yusuf \\ Faculty of Nursing Universitas Airlangga \\ Surabaya, Indonesia
}

\begin{abstract}
Social isolation is the decreasing ability to the interaction that appears in social isolation clients. If left untreated, social isolation symptoms may worsen the patient's condition, which may lead to the emergence of hallucinations and even the risk of suicide. The purpose of this study was to explain the effect of Social Skills Training to Social isolation on the change of ability to interact. This study used quasi-experimental design, with sampling method using total sampling. The population of this study consisted of $\mathbf{4 3}$ clients in Flamboyan ward, Menur Mental Hospital, Surabaya. A number 30 respondents were found to meet the inclusion criteria. The independent variable was Social Skills Training, and the dependent variable was the ability of interaction (cognitive, affective and behavioral) Data collecting was performed using observation sheets on the ability of interaction (cognitive, affective and behavioral). Data were analyzed using Wilcoxon Signed Rank test and Mann-Whitney $T$ test. Results showed significant increase $\mathbf{p}=\mathbf{0 . 0 0 0}$ (p-value < $0,05)$ analysis, it can be concluded that social skills training can improve the ability of interaction (cognitive, affective and behavioral in Social isolation clients. Based on the study, optimal provision of Social Skills Training along with in-depth approach can improve social skills and adaptive behavior in Social isolation clients. Therefore, the provision of effective generalist interventions and more indepth approach are needed to improve social skills and adaptive behavior of Social isolation client.
\end{abstract}

Keywords: cognitive, affective and behavioral, Social isolation, Social Skills Training

\section{INTRODUCTION}

Mental disorders are a maladaptive response to a stressor on the inside and outside environment, relate to the feelings and behaviors that are inconsistent culture/customs / local norms that affect the individual's social interaction, as well as the functions of the body [1]. Based on data from Riskesdas basic health research (2013) the prevalence of severe mental disorders Indonesia's population of 1.7 per mil. Most severe mental disorders in Yogyakarta (2.7\%), Aceh $(2.7 \%)$, South Sulawesi $(2.6 \%)$, Bali $(2.3 \%)$, Central Java $(2.3 \%)$ and East Java (2.2\%), while according to the East Java Provincial health Office 2014 visit people with mental disorders (ODGJ) to health care facilities as much as 595.873 93.387 inhabitants souls most in Sidoarjo, Surabaya 92.061 inhabitants, Malang 38.843 inhabitants, 37.310 Coarse sand soul, and Mojokerto 4.581 inhabitants. One type of severe mental disorder is schizophrenia. Social isolation is one of the negative symptoms of schizophrenia [2].

Social isolation is a condition when an individual has decreased to interact so that patients feel rejected, not accepted, lonely and unable to build relationships with others [3]. Social isolation impaired patients interact and experience the behavior does not want to communicate, preferring silence and shy away from others. Humans are social beings that can not be separated from the activities that constantly interact and influence the reciprocal relationship between people's needs and to sustain life [4].

Social isolation is a major factor relationship disorder; it is social isolation caused by impaired self-concept of chronic low self-esteem that can cause problems is difficult to develop a relationship, as a result, will suffer a setback in the form of a decrease in activity resulting in less attention to appearance and personal hygiene. The journey from past behavior and the behavior alone would result in behavior does not match reality then cause hallucinations. Hallucinations negative stressors will cause violent behavior occurs even risk injuring themselves [5].

Efforts nursing actions can be done to overcome the problem of interaction disorders in patients with mental disorders, especially social isolation of patients aims to train the client to do the interaction socially so that clients feel comfortable when dealing with others. One act of nursing that 
includes psychosocial therapy group is Social Skills Training (SST). Exercise social skills or what is often called the Social Skills Training (SST) administered to patients with impaired social isolation to practice the skills in relationships with others, and the environment optimally aimed to teach the ability to interact with a person with another person [4]. Interest Social Skills Training (SST) is to reduce anxiety improve self-control in a clan with social phobia, improve the ability of clients in joint activities, social work and improve client schizophrenia [6].

According to Rebecca meaning of friendship as an interpersonal relationship between two people who are producing and positive characteristics of mutual respect [7]. A study that links personality with a role in the friendships made [8], found that people who experience a bad mood and depression indicate interpersonal rejection by his friends than people who are not depressed. Compared with people who are not depressed, depressed individuals reported less social support networks and

smaller. From the results of the evaluation in the room Flamboyan, RSJ Menur Surabaya client can communicate well because in the room the client is given therapeutic nursing care and therapeutic group activities psycho-pharma.

Social Skills Training as one of behavior modification techniques have been widely performed and studied the level of success. Effectively used to improve one's ability to interact, increasing self-esteem, improve performance and lower levels of anxiety. This therapy can be given to the client; schizophrenia, clients depression, anxiety and social phobias are experiencing problems of social isolation, low self-esteem, violent behavior and anxiety [9]. Renidayati develop a module Social Skills Training on client social isolation by referring to the four phases of Social Skills Training stated Stuart and Laraia [10], which is to train the client's ability to communicate, make friends, train the ability to conduct joint activities, as well as face difficult situation, using modeling, role play, feedback and transfer training [11].

Several studies have linked the Social Skills Training (SST) of the patient's social isolation have been conducted [12], one of which is the result of research on the application of therapy Social Skills Training on the client using the social isolation theory approach Dorothy E. Johnson's Behavioral System Model in the village Balumbang Jaya subdistrict Bogor Barat Bogor, the results obtained are clients able to demonstrate an increase in communication skills verbal and non-verbal and able to interact with others who are nearby. Research on the application of exercise therapy social skills in client social isolation and low self-esteem with the approach Model interpersonal relationships Peplau at Dr Marzoeki Mahdi Bogor with the results of the exercise of social skills can improve socialization skills in client social isolation and low self-esteem, all clients have been able to speaks good exercise, exercise speaks to establish friendships; exercise speaks to cooperate and exercise speaks to face a difficult situation.

Based on the observations made by the researcher, the researcher is interested in conducting research on the influence of Social Skills Training: making friends on the ability of social interaction in patients with social isolation.

\section{METHODS}

This study with a quantitative method using quasiexperimental design population in this study all clients of social isolation and based on data from Surabaya Menur Mental Hospital patient population in social isolation in a ward as many as 43 clients. Based on the inclusion and exclusion criteria that have been determined by researchers, the sample size in this study were 30 respondents 15 respondents were divided into treatment group and control group of 15 respondents. This study uses a total sampling. Collecting data in this study using the instrument in the form of checklist to collect data on Social Skills Training, developed by Renidayati [11]. Observation sheet consisting of six cognitive and affective aspects six by the way filled by researchers associated with the client's ability to interact socially. Observation sheet consisting of six aspects of behavioral assessment when interacting can be measured by the researchers directly. These observations concerning the theories and concepts [5] [13]. Data processing by editing, coding, processing, and cleaning. Statistical analysis is used univariate and bivariate analysis Wilcoxon Signed Rank Test and Mann-Whitney.

\section{RESULTS}

The most of the Respondents of the control group or the treatment group 26-35 years old. Of $47 \%$ or 7 respondents from the treatment group and $47 \%$ or 11 respondents of the control group. Data from the range are school education until college showed that most respondents had an elementary education. By $67 \%$ or 10 respondents in the treatment group and $47 \%$ or 7 respondents in the control group. All respondents never go to school and not found respondents to the higher education. Job history data shows the average respondent does not have a job, amounting to $94 \%$ or 14 respondents in the treatment group and $100 \%$ or 15 respondents in the control group who did not have a job. Marital status data indicates the majority of respondents are unmarried, by $89 \%$ or 16 respondents in the treatment group and $100 \%$ or 18 respondents in the control group. The Frequency data is treated showed most respondents admitted to one that is equal to $13 \%$ or 2 respondents in the treatment group and by $6 \%$ or 1 respondent in the control group, while twice that is equal to $13 \%$ or 2 respondents in the treatment group and by $20 \%$ or 3 respondents in the control group. Most of the treatment group and the control group was more than twice that of $74 \%$ or 11 respondents. Medical diagnostic data shows the majority of respondents have a medical diagnosis of schizophrenia in the treatment group and control as much as $100 \%$. 
Table 1 Distribution of respondents based on cognitive abilities before and after the Social Skills Training

\begin{tabular}{|c|c|c|c|c|c|c|c|c|c|}
\hline \multirow{3}{*}{ No } & \multirow{3}{*}{$\begin{array}{l}\text { cognitive } \\
\text { abilities }\end{array}$} & \multicolumn{4}{|c|}{ treatment group } & \multicolumn{4}{|c|}{ Control group } \\
\hline & & \multicolumn{2}{|c|}{ Pre } & \multicolumn{2}{|c|}{ Post } & \multicolumn{2}{|c|}{ Pre } & \multicolumn{2}{|c|}{ Post } \\
\hline & & $\sum$ & $\%$ & $\sum$ & $\%$ & $\sum$ & $\%$ & $\sum$ & $\%$ \\
\hline 1 & Good & 0 & 0 & 4 & $\begin{array}{l}2 \\
7\end{array}$ & 0 & 0 & 0 & 0 \\
\hline 2 & Enough & 2 & 13 & 11 & $\begin{array}{l}7 \\
3\end{array}$ & 3 & 20 & 6 & 40 \\
\hline \multirow[t]{2}{*}{3} & Less & 13 & 87 & 0 & 0 & 12 & 80 & 9 & 60 \\
\hline & Total & 15 & 100 & 15 & $\begin{array}{l}1 \\
0 \\
0\end{array}$ & 15 & 100 & 15 & 100 \\
\hline \multirow[t]{2}{*}{$\begin{array}{l}\text { Stat } \\
\text { istic } \\
\text { test }\end{array}$} & $\begin{array}{c}\text { Wilcoxon } \\
\text { Signed } \\
\text { Rank } \\
\text { Test }\end{array}$ & \multicolumn{4}{|c|}{$\mathrm{p}=0,000$} & \multicolumn{4}{|c|}{$\mathrm{p}=0,083$} \\
\hline & $\begin{array}{c}\text { Mann } \\
\text { Whitney } \\
\text { Test }\end{array}$ & \multicolumn{8}{|c|}{$\mathrm{p}=0,000$} \\
\hline
\end{tabular}

Table 2. Distribution of respondents by affective abilities before and after the Social Skills Training

\begin{tabular}{|c|c|c|c|c|c|c|c|c|c|}
\hline \multirow{3}{*}{ No } & \multirow{3}{*}{$\begin{array}{l}\text { Affective } \\
\text { ability }\end{array}$} & \multicolumn{4}{|c|}{ Treatment group } & \multicolumn{4}{|c|}{ Control Group } \\
\hline & & \multicolumn{2}{|c|}{ Pre } & \multicolumn{2}{|c|}{ Post } & \multicolumn{2}{|c|}{ Pre } & \multicolumn{2}{|c|}{ Post } \\
\hline & & $\sum$ & $\%$ & $\sum$ & $\%$ & $\sum$ & $\%$ & $\sum$ & $\%$ \\
\hline 1 & Good & 0 & 0 & 0 & 0 & 0 & 0 & 0 & 0 \\
\hline 2 & Enough & 0 & 0 & 9 & 60 & 0 & 0 & 0 & 0 \\
\hline \multirow[t]{2}{*}{3} & Less & $\begin{array}{l}1 \\
5\end{array}$ & $\begin{array}{c}10 \\
0\end{array}$ & 6 & 40 & $\begin{array}{l}1 \\
5\end{array}$ & $\begin{array}{c}10 \\
0\end{array}$ & $\begin{array}{l}1 \\
5\end{array}$ & 100 \\
\hline & Total & $\begin{array}{l}1 \\
5 \\
\end{array}$ & $\begin{array}{c}10 \\
0 \\
\end{array}$ & $\begin{array}{l}1 \\
5 \\
\end{array}$ & $\begin{array}{c}10 \\
0 \\
\end{array}$ & $\begin{array}{l}1 \\
5\end{array}$ & $\begin{array}{c}10 \\
0 \\
\end{array}$ & $\begin{array}{l}1 \\
5 \\
\end{array}$ & 100 \\
\hline \multirow[t]{2}{*}{$\begin{array}{l}\text { Statisti } \\
\text { c test }\end{array}$} & $\begin{array}{c}\text { Wilcoxo } \\
n \text { Signed } \\
\text { Rank } \\
\text { Test }\end{array}$ & \multicolumn{4}{|c|}{$\mathrm{p}=0,002$} & \multicolumn{4}{|c|}{$\mathrm{p}=1,000$} \\
\hline & $\begin{array}{c}\text { Mann } \\
\text { Whitney } \\
\text { Test }\end{array}$ & \multicolumn{8}{|c|}{$\mathrm{p}=0,000$} \\
\hline
\end{tabular}

Based on table I, statistical test results using Wilcoxon Signed Rank test found no increase in cognitive ability before and after the Social Skills Training: friendship, with $\mathrm{p}=0.000$, mean $\mathrm{p}<\alpha<0.05$ then $\mathrm{H} 1$ accepted. The statement concluded H1 accepted no influence Social Skills Training: friendship on cognitive abilities. Mann-Whitney Test showed significant $\mathrm{p}=$ $0.000 \mathrm{p}<\alpha<0.05$. These results showed no significant differences between treatment groups were already getting Social Skills Training: a friendship with the control group.

Table 2 showed that statistical test results using Wilcoxon Signed Rank Test affective abilities found no change in the treatment group between before and after the Social Skills
Training: friendship, with $\mathrm{p}=0.002$, mean $\mathrm{p}<\alpha<0.05$ then $\mathrm{H} 1$ accepted. The statement concluded $\mathrm{H} 1$ accepted no influence Social Skills Training: friendship the ability of clients to social isolation effective. Results of Mann-Whitney Test showed significant $\mathrm{p}=0.000 \mathrm{p}<\alpha<0.05$. These results showed no significant differences between treatment groups were already getting Social Skills Training: a friendship with the control group.

Table 3 showed that statistical test results using Wilcoxon Signed Rank test found no change in behavior in the experimental group between before and after the Social Skills Training: friendship, with $\mathrm{p}=0.000$, mean $\mathrm{p}<\alpha<0.05$ then $\mathrm{H} 1$ accepted. The statement concluded $\mathrm{H} 1$ accepted no influence Social Skills Training: a friendship on the behavior of clients with social isolation. Results Test Mann-Whitney test showed significant $\mathrm{p}=0.000 \mathrm{p}<\alpha<0.05$. These results showed no significant differences between treatment groups were already getting Social Skills Training: a friendship with the control group.

Table 3. Distribution of respondents by psychomotoric abilities before and after social skills training

\begin{tabular}{|c|c|c|c|c|c|c|c|c|c|}
\hline \multirow{3}{*}{ No } & \multirow{3}{*}{$\begin{array}{l}\text { Psychomot } \\
\text { or ability }\end{array}$} & \multicolumn{4}{|c|}{ Treatment group } & \multicolumn{4}{|c|}{ Control group } \\
\hline & & \multicolumn{2}{|c|}{ Pre } & \multicolumn{2}{|c|}{ Post } & \multicolumn{2}{|c|}{ Pre } & \multicolumn{2}{|c|}{ Post } \\
\hline & & $\sum$ & $\%$ & $\sum$ & $\%$ & $\sum$ & $\%$ & $\sum$ & $\%$ \\
\hline 1 & Good & 0 & 0 & $\begin{array}{l}1 \\
5\end{array}$ & 100 & 0 & 0 & 0 & 0 \\
\hline 2 & Enough & 4 & 27 & 0 & 0 & 3 & 20 & 3 & 20 \\
\hline \multirow[t]{2}{*}{3} & Less & 11 & 73 & 0 & 0 & 12 & 80 & 12 & 80 \\
\hline & Total & 15 & 100 & $\begin{array}{l}1 \\
5\end{array}$ & 100 & 15 & 100 & 15 & 100 \\
\hline \multirow{2}{*}{$\begin{array}{l}\text { Statist } \\
\text { ic test }\end{array}$} & $\begin{array}{l}\text { Wilcoxon } \\
\text { Signed } \\
\text { Rank Test }\end{array}$ & \multicolumn{4}{|c|}{$\mathrm{p}=0,000$} & \multicolumn{4}{|c|}{$\mathrm{p}=0,083$} \\
\hline & $\begin{array}{c}\text { Mann } \\
\text { Whitney } \\
\text { Test }\end{array}$ & \multicolumn{8}{|c|}{$\mathrm{p}=0,000$} \\
\hline
\end{tabular}

\section{DISCUSSION}

Social Skills Training before the decreased ability of social interaction in the cognitive abilities of the client communications is less obvious, is not heard by the opponent talk, can not express feelings with others, do not grasp the information and respond, do not ask if there is a sentence that does not understand. Affective abilities client is not able to offer help to others, not being able to ask for help from others, not able to say thank you when receiving help from others. Ability greeting behavior when met, can not introduce themselves, lack of eye contact. It is appropriate according to Keliat and Akemat (2009) Social isolation is a condition when an individual has decreased or even completely unable to interact with others in the vicinity [14]. Patients may feel rejected, not accepted, lonely and unable to build meaningful relationships with others. 
After the Social Skills Training increased interaction capability in the social, cognitive abilities client can communicate clearly, be heard by the other person, can express feelings with others, can grasp the information and respond, ask if there is a sentence that does not understand. Affective abilities client can offer help to others, can ask for help from others, can say thank you when receiving help from others. Ability behavior can be greeting when met, can introduce yourself, no eye contact. According to Nasir, an important factor affecting social interaction, namely imitation: learning by imitating and following the behavior of someone who will give consideration as to whether the behavior needs to be improved, surviving or even altered, a suggestion: the process of social interaction when an individual receives a view of the individual others without getting criticism in advance, identification: the desire in a person to be the same with others in the interaction, sympathy: the person who feels interested in others due to pressing the psychological atmosphere of other people who are having problems [15].

The results of the study showed statistical tests of cognitive ability in the treatment group gained value $\mathrm{p}=$ 0.000, which means no influence Social Skills Training: friendship toward social interaction skills (cognitive) before and after the Social Skills Training: friendship. The results are consistent with research concept, stating the client schizophrenia and depression decreased ability to interact, always think negative about themselves other people and the surrounding environment, pessimistic, always look down on themselves, can be enhanced by providing a social skills training which is done first by the therapist, followed by the client, given feedback, and in the evaluation of its implementation [16].

Results of research by statistical test demonstrated the ability effective in the treatment group $\mathrm{p}$-value $=0.000$, which means no influence Social Skills Training to changing social isolation affective abilities before and after the Social Skills Training. The results are consistent with [17]. Social Skills Training given to clients of schizophrenia decreased the ability to interact with others, to have negative thoughts with regard himself incapable. So that after a given Social Skills Training then positive thoughts on the social isolation of patients will increase. While most of the decline in affective abilities in the control group it is by the theory depression and other mental disorders such as schizophrenia are more common in women [18]. Women are more often exposed to environmental stressors and lower the threshold to stressors than men. Study shown that effectively clients with social isolation felt tired and slow in spending time, sadly, blunted affect, and lack of motivation [1]. Affective responses indicate a feeling. Assessment of stressors affectively non-specific and usually a reaction expressed as emotional anxiety. Affective responses that emerged include sadness, fear, anger,

happy, accept, believe, anticipate, and was pleasantly surprised. The increased affective response the respondent after the Social Skills Training for existing clients increase positive feelings and can appreciate the individual, others and the environment so that the respondent can turn a negative into a positive feeling that eventually will bring a positive attitude as well as taught transform negative feelings to be positive.

Results of research by statistical tests showed the treatment group p-value $=0.000$, which means no influence Social Skills Training to changes in social interaction behavior before and after the Social Skills Training. The results are consistent as Social Skills Training can reduce anxiety improve self-control in a clan with social phobia, improve the ability of clients in joint activities, social work and improve client schizophrenia [6].

\section{CONCLUSION}

Improving the ability of the client's behavior to social isolation after following the Social Skills Training interventions, supported the implementation of vocational training communicated constantly and continuously trained well until it becomes a habit for the client. Before becoming a habit for the client given the Social Skills Training, practice the skills taught done first by researchers, were attempted by the client, are given feedback on the success that has been done by the client and the client is given the task to practice back in practice the skills that have been trained to clients and nurses were there all subjects.

\section{REFERENCES}

[1] M. C. Townsend, Psychiatric Mental Health Nursing Concepts of Care in Evidence-Based Practice, 6th ed. Philadelphia: F.A Davis Company, 2009.

[2] S. Nyumirah, "Peningkatan Kemampuan Interaksi Sosial (Kognitif, Afektif Dan Perilaku) Melalui Penerapan Terapi Perilaku Kognitif Di Rsj Dr Amino Gondohutomo Semarang," Keperawatan Jiwa, vol. 2, no. 121-128, pp. 121-128, 2013.

[3] B. A. Keliat and Akemat, Model Keperawatan Profesional Jiwa. Jakarta: EGC, 2009.

[4] E. Berhimpong, S. Rompas, and M. Karundeng, "Socialization Skills Training Influence Ability To Interact Clients Social Isolation in Mental Hospital Prof Dr V L Ratumbuysang Manado,” 2016.

[5] B. A. Keliat, R. U. Panjaitan, and N. Helena, Proses Keperawatan Kesehatan Jiwa. Jakarta: EGC, 2005.

[6] C. R. Kneisl and E. Trigoboff, Contemporary Psychiatric-Mental Health Nursing, 3rd Edition. New Jersey: Pearson Prentice Hall., 2004.

[7] Rebecca G. Adams, "Definitions of friendship in the third age: age, gender, and study location effects," $J$. Aging Stud., vol. 14, no. 1, pp. 117-133, 2000.

[8] S. M. Campbell, Intimate friendship. New York: 
McGraw-Hill, 2002.

[9] L. Nelson-Zlupko, E. Kauffman, and M. M. Dore, "Gender differences in drug addiction and treatment: Implications for social work intervention with substance-abusing women," Soc. Work, vol. 40, no. 1, pp. 45-54, 1995.

[10] G. W. Stuart, Principles and Practice of Psychiatric Nursing-E-Book. Elsevier Health Sciences, 2014.

[11] Renidayati, "Pengaruh social skill training pada klien isolasi sosial di Rumah Sakit Jiwa Prof HB Saanin Padang," Indonesia, 2008.

[12] S. Williams White, K. Keonig, and L. Scahill, "Social skills development in children with autism spectrum disorders: A review of the intervention research," $J$. Autism Dev. Disord., vol. 37, no. 10, pp. 1858-1868, 2007.

[13] G. W. Stuart, Buku Saku Keperawatan Jiwa, 5th ed.
Jakarta: EGC, 2007.

[14] B. A. Keliat and S. Akemat, "Keperawatan kesehatan jiwa komunitas: CMHN (Basic Course)," Jakarta EGC, 2011.

[15] A. Nasir, Komunikasi dalam Keperawatan Teori dan Aplikasi. Jakarta: Salemba Medika, 2009.

[16] C. Gold et al., "Individual music therapy for mental health care clients with low therapy motivation: multicentre randomised controlled trial," Psychother. Psychosom., vol. 82, no. 5, pp. 319-331, 2013.

[17] M. Bounded, "Vocational social skills training for schizofrenia.," 2004.

[18] M. Kuntjoro, Mengenal Gangguan Jiwa. 2006. 